\title{
The tragedy of painless needs
}

\author{
John D Loeser MD
}

\section{JD Loeser.}

The tragedy of painless needs.

Pain Res Manage 2000;5(3):228-232.

Intractable pain demands the attention of both the patient and the physician. However, modern science and medicine cannot and should not promise the abolition of pain and suffering. The novel, Ingenious Pain, by Andrew Miller offers profound insights into the world of pain. Not all painful experiences in life are deleterious, nor should they all be prevented.

Key Words: Pain; Ronald Melzack; Suffering

\section{La tragédie des besoins de soulagement de la douleur}

RÉSUMÉ: La douleur incurable retient l'attention à la fois du patient et du médecin. Cependant, la science et la médecine d'aujourd'hui ne peuvent ni ne doivent aspirer à l'élimination de la douleur et des souffrances. Le roman intitulé Ingenious Pain d'Andrew Miller explore le monde de la douleur sous tous ses angles. Les expériences douloureuses de la vie ne sont pas toutes délétères, et il n'est pas souhaitable de toujours les prévenir.
$\mathrm{T}$ his article is dedicated to Ronald Melzack. He has been a great source of inspiration and a wonderful friend since we first met in Issaquah, Washington in 1973. We were summoned to that former nunnery by John Bonica - Ron because he was already one of the most revered pain researchers, and I because I was a useful foot soldier. Although Ron was already very well known for his seminal work on the gate control theory, his scope of interest was broad and his contributions to neuroscience immense. I will never forget Ron's foray into neurosurgery at that meeting; he showed a movie of a craniectomy performed under somewhat primitive circumstances without anesthesia or a valid International Classification of Diseases code to justify the operation. A psychologist in the audience fainted at the sight and struck his head while falling. Someone called for a neurosurgeon, and my career in pain research and management was launched.

My debt to Ron began early. Scientists and clinicians responded to Dr Bonica's second summons and met again in
Florence, Italy in 1975 at the First World Congress of Pain, sponsored by the recently founded International Association for the Study of Pain. Ron had lived and studied in Pisa, just a few miles away, and he continued my education in pain as well as in Italian food, wines, art and architecture. It was there that I first met Lucy Melzack and fell in love with her as well as her husband. Ron and I had several enologically augmented discussions overlooking the Arno in Florence and started working on a paper about pain after spinal cord injury (1). We thought that this pain syndrome indicated that pain generation occurred in the brain - not because of messages travelling up hardwired pathways. Ron developed the neuromatrix theory while I went back to operating on patients with pain and trying to discern peripheral mechanisms for neuropathic pain states. Good luck enabled me to write one other paper with him in the past year. I hope that his retirement will mean that we can spend more time together thinking about pain (2).

Ron's papers and lectures have been on the cutting edge of 
many aspects of pain research. He has trained an entire generation of pain researchers who carry on the traditions that he has established. In his spare time, he has transcribed and edited stories of the native people of Canada, so that their traditions would not die out. These books are as charming as his science is exciting. He has been honoured by professional societies, both national and international, as well as by the government of Canada. Now he has retired, and his colleagues, students and friends have prepared this collection of articles in his honour. He has challenged all of us to consider not only the neurosciences of pain but also the ethical and moral issues of pain research, and the treatment of those who complain of pain.

This article is a modest response to the enlightenment that Ron has given in the past 40 years. What is pain, and what is its use to those who endure its barbs? Can teleological explanations be used for the existence of transient pain or acute pain and then generalized to chronic pain? Is a pain-free world something that human societies should aspire to? Will developments in neuroscience enable us to find ideal, long lasting drugs that will eliminate pain and suffering? Does pain have some usefulness? If so, to whom and when? Do cultures need pain to perpetuate their traditions? Some of these issues are the focus of the present article.

One of Ron's most widely read articles was published in Scientific American in 1990 (3). Entitled "The tragedy of needless pain", the article focused on the gap between what was then known to scientists and to some clinicians about narcotics in pain management and what was actually offered to most patients. Its theme rode on the crest of the North American opiate war; we could do much better for our patients if we used narcotics more liberally. The article did not separate the patient management issues of chronic pain from issues of palliative care and acute pain. Readers were informed that increased use of narcotics could be the solution to much of the suffering endured by chronic pain patients. What were missing, of course, were any data indicating that patients with chronic, nonmalignant pain would have their lives improved by the widespread use of narcotics. Not that there was much evidence to the contrary. Nonetheless, Ron's strong statement was wishful or political, but not scientifically based. He appropriately demolished the opiophobic arguments that addiction liability was real and that tolerance would prevent effective therapy. What he did not address was whether there could be treatments with better outcomes than narcotics offered and what the risk was that the ready use of narcotics might forestall more effective treatments.

Everyone who deals with chronic pain patients knows that self-reported pain levels are an inadequate, although important, method of assessing the success of treatment. It has been recognized, from a wide array of studies in many countries, that chronic pain has many psychological, sociological and cultural components. I am still awaiting research to show the effects of narcotics on these potential pain generators and perpetuators. Meanwhile, we cannot ignore the large number of studies that indicate a role of sociocultural influences such as job satisfaction, wage replacement ratio, educational level or length of employment on submission of a claim for disability due to pain. Furthermore, Mechanic (4) and others have shown that the symptoms so prevalent in Western society do not necessarily mean that health care will be consumed or disability claimed. Kroenke and Mangelsdorff (5) revealed that no more than $15 \%$ of patients with symptoms who consult a primary care provider are found to have structural or physiological abnormalities to explain those symptoms when followed for three years. Waddell et al (6) showed that the fears of patients with low back pain, not reported pain level, are the major determinants of response to treatment and return to work. Narcotics may be effective in blunting nociception, and in reducing the perception and emotion generated by a noxious stimulus or by certain injuries to the nervous system. To the extent that a patient's pain behaviours can be traced to such factors, narcotics may be useful treatment. This utility does not apply to all patients; this is the point that I wish to make.

I will not discuss the problems engendered by side effects of narcotics or by their illegal uses and diversion. I am not opiophobic, but remain unconvinced that simply increasing the use of narcotics for chronic pain will reduce the number of patients or the costs to society. Furthermore, the recognition of a painful stimulus is not a line-labelled phenomenon from the periphery to the cerebral cortex. The brain does not sit passively at the top of the neck awaiting messages from nociceptors. Modulation occurs both up- and downstream in the processing of information. Affects, past experiences, expectations, fears and stimulus qualities all influence the perception of and responses to pain. Medications other than narcotics may be more effective in altering these brain and spinal systems; physical and psychological treatments may also be superior to narcotics or other drugs.

Pain requires consciousness - an emergent property of the brain that is not readily explained by even a detailed examination of individual nerve cells and their connections. Chapman and Nakamura (7) recently eloquently wrote that "pain is a dynamic product of a self-organizing brain". Psychological processes can alter the qualities of subjective experiences and change observable patterns of central processing seen on functional magnetic resonance imaging, positron emission tomography scans and electrical recordings of brain function. Like consciousness, pain is an emergent property, not a quantifiable amount of something to be measured with a magical dipstick.

Karl Marx (8) once wrote: "Physical pain is the antidote to mental pain". What could he have meant? One possibility is that the complaint of pain is taken to mean that something has gone wrong within the body, even when it is the relationship to the outside world that has been broken. The complaint of pain legitimates the failure to carry out one's expected activities. Another possibility is that Marx recognized the role of distraction as a potential mechanism of pain control. Perhaps he was expressing the idea that people were expected to suffer in a variety of ways so as to get their needs met. Painless needs might undermine health and impair the relationships between an individual and society. Many believe that work- 
ing for a goal and suffering en route are useful for the individual. It has long been said that one rarely values that which is free. Furthermore, experiencing pain may be the way that we are able to learn about suffering and its uses. As well as the tragedy of needless pain, we may also envision the tragedy of painless needs.

It is often the case that writers of fiction are years ahead of scientists and physicians. Miller's (9) book Ingenious Pain fits this generalization: "Pain, friends, is from the devil. It is his touch, his caress. His venomous embrace!"

Set in the 18th century, the novel's primary character is a rural lad, James Dyer, who was born without the ability to perceive pain. Deemed peculiar as an infant, perhaps because of his mother's suspected dalliance, he never cried and did not speak until later than customary. The proof of his peculiarity comes when James is old enough to climb a tree and attempt to fly. With obvious broken bones, he sheds not a tear. From that time on, he is marked, and when his family is devastated by smallpox, he joins a mountebank in a travelling circus, attracting paying customers by having a variety of customarily painful things done to him. His wounds heal rapidly, almost instantly, as if by magic.

The boy was incapable of suffering! The boy had never suffered in his life. More than this, any wound he received healed at such a rate that one would almost sit and watch the flesh draw together, knit, blanch, resolve.

To earn money from circus crowds, James has to learn to imitate suffering, to study it almost like a foreign language.

He must learn to imitate suffering, he must study it, its effects. He should study it like a foreign language and for this he must have a teacher...At first James did not understand what was required of him. The man's antics were utterly mysterious, but Leigh persisted and the boy caught on...It was everywhere, this thing called suffering.

James is soon kidnapped by a wealthy country gentleman with a fascination for the bizarre, who, for the purposes of scientific investigation, keeps a living museum of freaks and misfits. The interrogation continues.

'You really feel nothing, my friend?' James shakes his head. He does not care to be pitied.

'No pain?'

'Never.'

James escapes, joins the mountebank again, and is shanghaied aboard a Royal Navy warship, where he is treated with a brutality for which the British navy in the 18th century was renowned. The hardened ship's surgeon, Mr Munro, is astonished at what he sees.

What amazed Mr Munro upon this occasion was that the boy, though stunned, showed no evidence of the suffering that must be consequent upon such a thrashing; and what amazed him further, what amazed us all, was the speed with which the welts on his back disappeared, for he was not, I think, in the sick-bay above a single day before he declared himself fit for his duties.

James is able to endure not only the physical damage but also the psychological abuse because nothing can touch him; he lacks any response to physical or psychological trauma.

James eventually becomes the surgeon's assistant. His intellectual and manual talents come to the fore, and he subsequently joins his former chief in a lucrative civilian practice ashore. Although his surgical skills are exemplary, his ability to understand feelings and the relationships between people is deficient.
Munro's old sign comes down. A new one-Jms Dyer \& Rbt Munro, Surgeons - swings from the iron scroll above the door, and beneath its shadow come the citizens of the republic of pain: the chronic sufferers, and those struck down suddenly by some bloody disaster, and hustled in, faint, in the arms of friends. And most come out again, if not precisely healed, at least somewhat easier than when they entered, and all dazzled by the young man's skill, soothed by the elder's kindness. Some even die grateful.

Nothing seems to strike an emotional chord with him. As he says,

...the suffering of others did not trouble me in the least. I understood it only in so far as there existed a correlation between the sharpness of the pain and the fee that might be had for its relief.

There is even reason to believe that his inability to feel pain pushes him out of the class of humankind altogether, or at least makes him a man to beware of.

\section{James Dyer - well, he could hardly be said to be human} at all. A machine for cutting. An automaton. Dangerous.

Eventually, he quarrels with his associate over an apparently inappropriate relationship with the man's spouse and becomes a pariah in the community. His practice dies; he has no insight into the nature of his offenses.

James is rescued from the doldrums by the chance to win a competition to bring the new inoculation for smallpox to the Tsarina in St Petersburg. It is on this journey, through a ferocious blizzard, that he glimpses a woman fleeing male pursuers and rescues her, experiencing for the first time a message from his soul. "What is it to be alive? What does the girl feel that he does not?". This woman, who is called Mary, is a witch or some other strange being. She is later seen performing magical surgery upon James' chest; no bleeding occurs and no scar is left. He is able to communicate with Mary in a way that none of his companions can fathom; he senses that he has changed, as even his eventual benefactor, the Reverend, cannot help noticing.

He does not know exactly what has happened, only that it has happened. He does not understand how things have changed, only that they have. 
Dyer has somehow left the world of medical science and entered the world of mysteries, feelings and emotions. "In pain he discovers his history, and the air grows truculent with voices". In the encounter with pain, he appears to recover the human identity and personal past that his state of painlessness had erased or masked. Overcome by his suffering and by the realization of what he has not experienced in life, James has a mental breakdown, is returned to England and is institutionalized in a madhouse.

Back in England, treated more like a prisoner than a patient, James falls in love with one of his fellow inmates, a woman whose pointless death he is able to experience in an anguish that is new to him. "James is learning to survive, to bear pain; uncovering the springs of courage. Love is his teacher." Eventually he gains control over his feelings and is released from the asylum. He is unexpectedly and inexplicably reunited with the mysterious witch-like creature, Mary, whom he rescued in Russia. He is befriended by his companion on the Russian journey, the Reverend, under whose care James is able to live and die peacefully in the English countryside. During his stay with the Reverend James, now in full possession of the experience of both pain and suffering, rejects or abandons his former calling as a surgeon. The Reverend, of course, cannot resist a few pointed questions.

'Forgive me, Doctor, but you were once, so it seemed, impervious to its fangs. Pain I mean.'

'Not seemed, Reverend. I did not feign it. It was precisely as I said. I never had a moment's physical suffering until...well, until Petersburg. I begin to find it hard to believe in it myself. Suffice it to say, I have been making up for what I have missed.'

'He is quite gone, then?'

'Who, sir?'

'The old James Dyer.'

'Quite gone.'

The new James Dyer relives much of his childhood, experiencing the pain he missed when most of his family was wiped out by smallpox and when his sister went blind. He grieves over the death of Gummer, the mountebank who first showed him the real world, and he recognizes his shortcomings as a surgeon who did not understand suffering. He dies peacefully in the knowledge that he has found the meaningfulness of life in an attention to the needs of others.

Although no reader has the privilege of knowing the author's intent when he created a fictional work, this book sings to me about the tragedy of painless needs.

The inability to feel pain of any type is known medically as 'uniform congenital indifference to pain'. It is a very rare congenital abnormality. I have seen two brothers who had this condition and who were described subsequently in the medical literature. One died as a teenager, the other survived into early adulthood. Both sustained innumerable accidental and self-inflicted injuries that led to premature impairment and disability. Charcot joints of the lower extremity and spine were particularly destructive. Corneal abrasions led to opacities and poor vision. Recurrent pneumonia was noted, probably due to the lack of protective tracheal and laryngeal reflexes. In addition to their obvious physical problems, both boys had major psychological issues. They manipulated their environment by threatening self-inflected injury if they did not get their way. Normal interpersonal relationships did not seem to develop. Unfortunately, I did not know how to ask them about suffering when I saw them as a resident.

Miller's protagonist somehow escaped the physical ravages that accompany the absence of feeling pain; that is the author's prerogative, even though it may not match reality as we know it. A child who feels no pain is at risk for both physical and mental health. It is through pain that we learn suffering and, perhaps, other emotions. We learn how to defer gratification, to value what others can offer us and to develop into functional adults. James Dyer was deprived of these childhood experiences, and the deprivation of pain is what made him unable to cope with the needs of patients or social interactions of any type.

Not all pain is needless, not all human needs can be satisfied painlessly. If we narcotized our children and immunized them against pain, would they ever become adults? Would they ever learn the range of feelings and emotions that make life worth living? Lewis (10) believed that suffering was the pathway to goodness, although he recognized that "All arguments in justification of suffering provoke bitter resentment against the author". Could the religious explanations for suffering obscure the more fundamental human needs to learn through pain? Cassell (11) recently addressed the importance of physicians' concerns about the suffering of patients and how listening to the patient's story, rather than applying technology, is required. Is there a physician who has never felt pain and never suffered? Likely not. But there are certainly physicians who act as if their own experience with pain and suffering is irrelevant to the treatment of patients. Miller (9) tells us how Dyer's inability to experience pain relates directly both to his skills and to his deficiencies as a doctor. The deficiencies eventually overcame his superlative technical skills, and he was driven from his practice.

Illich (12) powerfully addressed similar issues in Medical Nemesis:

Now an increasing portion of all pain is man-made, a side-effect of strategies of industrial expansion. Pain has ceased to be conceived as a 'natural' or 'metaphysical' evil. It is a social curse, and to stop the 'masses' from cursing society when they are painstricken, the industrial system delivers them medical pain-killers. Pain thus turns into a demand for more drugs, hospitals, medical services, and other outputs of corporate, impersonal care and into political support for further corporate growth no matter what its human, social, or economic cost. Pain has become a political issue which gives rise to snowballing demand on the part of anesthesia consumers for artificially induced insensibility, unawareness, and even unconsciousness. 
Those who provide care to patients enmeshed in a worker's compensation system know all too well about this meaning of pain.

Great doctors are known not only for their knowledge or skill, but also for their humanity and understanding of the patient's physical and emotional needs. They make use of the nonspecific treatment effects that have always accrued to healers. Some pain is required to achieve this vaunted status. Those who have answered John Bonica's clarion call to make pain management an essential component of patient care have learned about the many meanings and contributing causes of painfulness. They have done so by listening both to their patients and to the messages that come from within their own minds. They recognize, as he did, that the relationship

\section{REFERENCES}

1. Melzack R, Loeser JD. Phantom body pain in paraplegics: Evidence for a central "pattern generating mechanism" for pain. Pain 1978;4:195-210.

2. Loeser JD, Melzack R. Pain: An overview. Lancet 1999;353:1607-9.

3. Melzack R. The tragedy of needless pain. Sci Am 1990;262:27-33.

4. Mechanic D. Medical Sociology. New York: Free Press, 1968.

5. Kroenke K, Mangelsdorff AD. Common symptoms in ambulatory care: incidence, evaluation, therapy, and outcome. Am J Med 1989;86:262-6.

6. Waddell G, Somerville D, Henderson I, et al. A fear avoidance beliefs between tissue damage and a response by the patient is not based on a line-labelled sensory system, but on the interplay of afferent information, past experience, expectations and the current affective state. Melzack is certainly correct that the greatest tragedy is a physician's failure to respond to a patient's pain. We attend to another person's pain because of our own experiences because we are denied the chance to feel another person's pain or suffering. This pain of maturation and human growth is needful, not needless. Pain and how it is addressed are woven into our culture; physicians and their patients derive meaning from symptoms. Ingenious Pain is a book every pain specialist should read. "All pain is real enough to those who have it; all stand equally in need of compassion." questionnaire (FABQ) and the role of fear avoidance beliefs in chronic low back pain and disability. Pain 1993;52:157-65.

7. Chapman CR, Nakamura Y. Pain and consciousness. Pain Forum 1999;8:113-23.

8. Marx K. Herr Vogt. New York: New Park Publications, 1982.

9. Miller A. Ingenious Pain. San Diego: Harcourt Brace, 1997.

10 Lewis CS. The Problem of Pain. New York: Macmillan, 1962:93.

11. Cassell EJ. Diagnosing suffering: a perspective. Ann Intern Med 1999; 131:531-4.

12. Illich, I. Medical Nemesis. New York: Random House, 1982.

\section{ERRATUM}

In the Summer 2000 issue of Pain Research \& Management (Volume 5, Number 2), Christine T Chambers $\mathrm{PhD}$, should have been identified as a Guest Editor of the Special Section on Pediatric Pain Management, in addition to Dr Patrick McGrath PhD.

\section{BOOK REVIEW}

Concise Encyclopedia of Chronic Fatigue Syndrome, edited by Roberto Patarca-Montero (2000). Haworth Medical Press, 10 Alice Street, Binghamton, New York 13904-1580, USA. ISBN 0789009226; US\$69.95; 160 pages.

This volume of 160 pages in soft covers is an alphabetic compendium describing such varied phenomena as allergies, anxiety disorders, circadian rhythms and of course fatigue and its corollaries. It is deliberately not comprehensive but is a handy source book and gives references for those interested in the topic, both professional and lay.

Harold Merskey DM Department of Psychiatry University of Western Ontario London, Ontario

\section{ADVERTISERS' INDEX}

Pain Research \& Management is a peer review Journal, financed almost entirely through advertising.

The companies advertising in this Journal have recognized the need to support high quality, Canadian, ethical journals, and to promote publishing of Canadian medical research.

Pulsus Group, the Canadian Pain Society and the readers of Pain Research \& Management appreciate the support of the following companies for making this issue possible:

\section{Aventis}

M-Elson . . . . . . . . . . . . . . . 180

Prescribing information . . . . . . . . . . . 222

\section{Parke-Davis}

Neurontin . . . . . . . . . . . IFC

Prescribing information . . . . . . . . . . . . 214

\section{Purdue Frederick}

Hydromorph Contin . . . . . . . . . . OBC

Prescribing information . . . . . . . . . . 220 


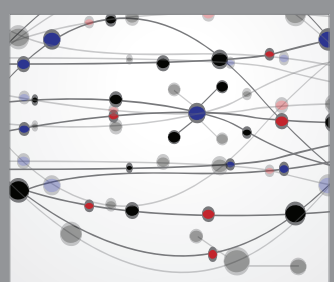

The Scientific World Journal
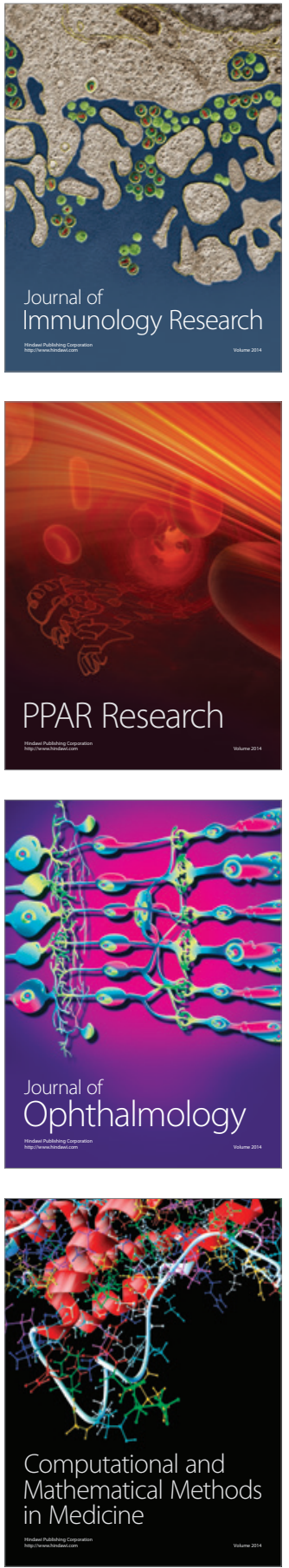

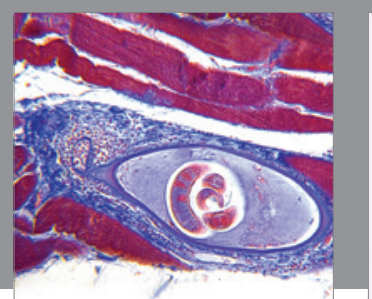

Gastroenterology Research and Practice

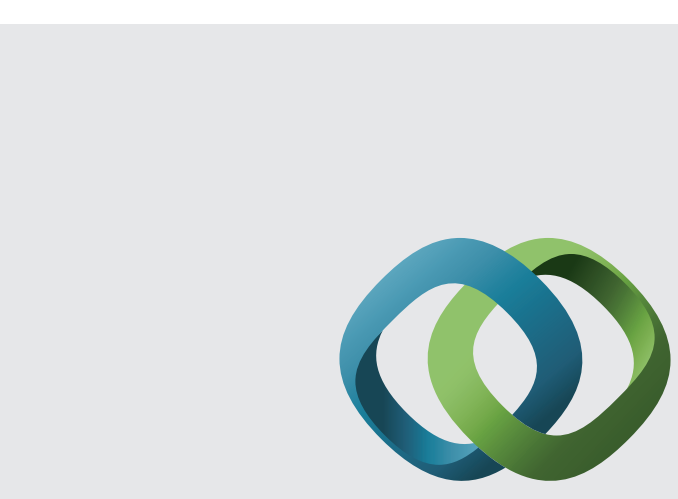

\section{Hindawi}

Submit your manuscripts at

http://www.hindawi.com
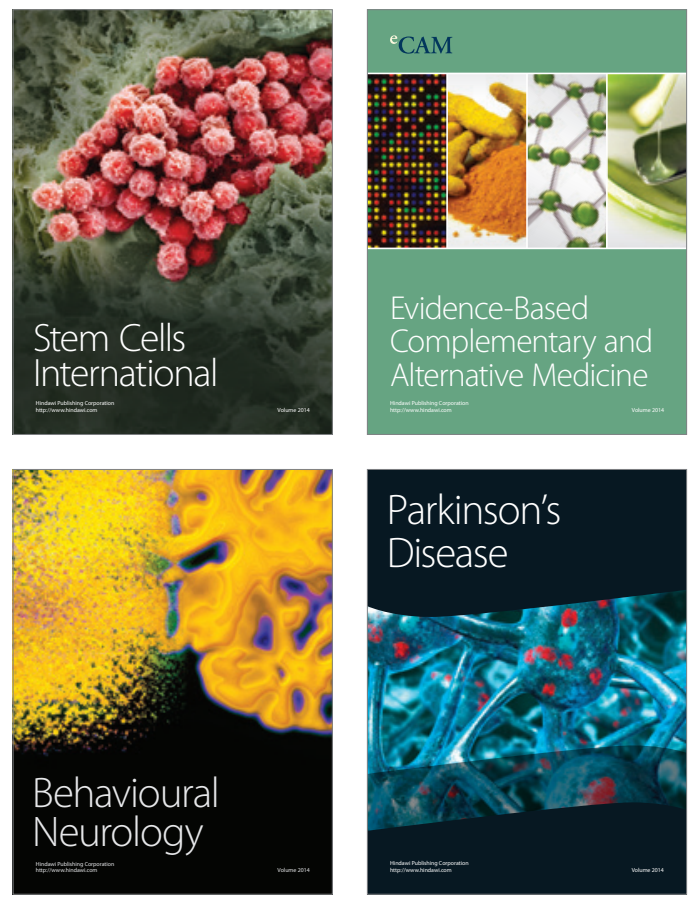
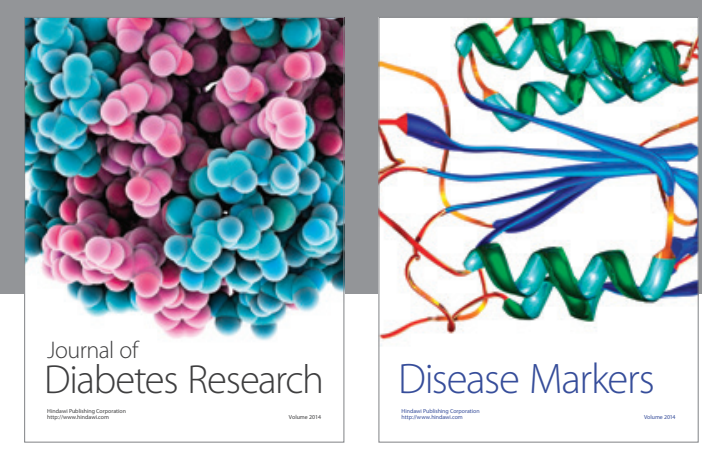

Disease Markers
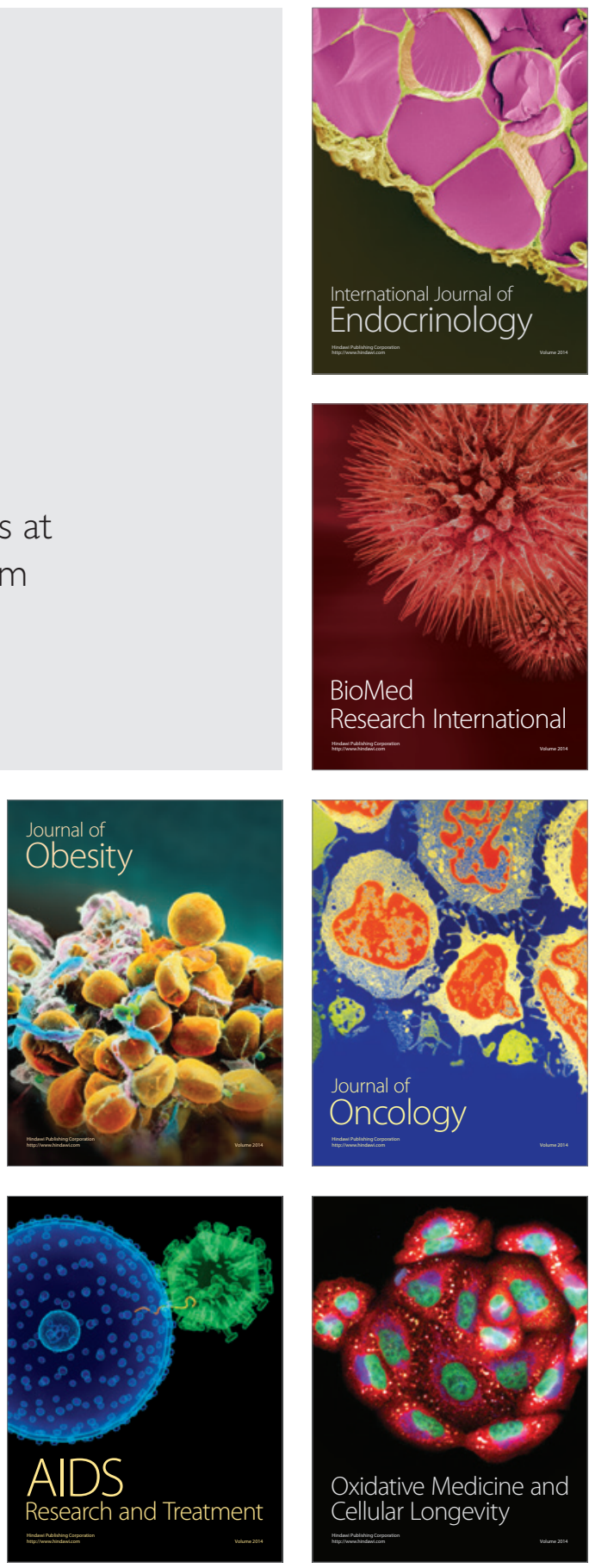